\title{
'خطة مقترحة للعمل في مجال السياحة الترويحية في محافظة أسوان
}

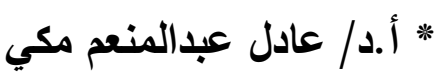

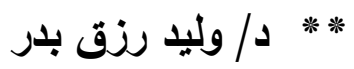

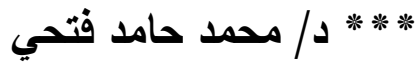

| الباحثة/ إيمان أحمد عبدالثافي

\section{المقدمة ومشكلة البحث:}

أصبحت السياحة بوجـه عـام والسياحة الترويحيـة بصفة خاصـة مـن أهم الصـناعات الخدميـة في جميع دول العـالم المتقدمة والناميـة علي حد سواء وذلك نتيجة المزايـا التي يتت تحقيقها من هذا النشاط سواء من الناحية الاقتصادية أو الاجتماعية ...الخ ، وتعتبر مصر من دن

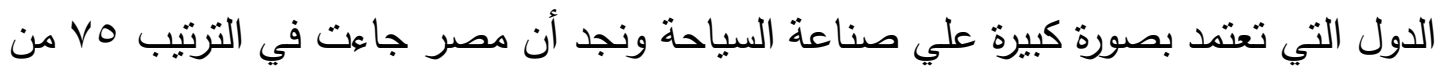

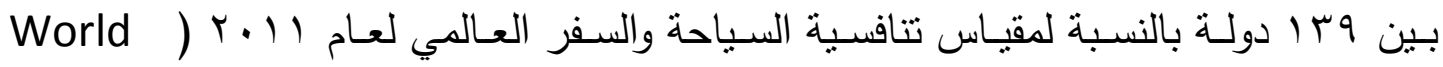

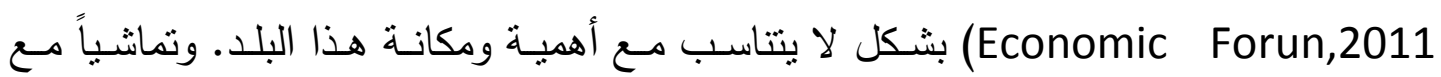

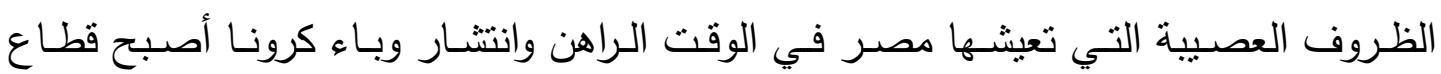
السياحة المصري في أثد الحاجة للبحث عن عدة وسائل يستطيع من خلالها تحسين الصورة الذهنية لمصر كمقصد سياحي والعمل علي جذب العديد من الأسواق لهصر بصورة تتناسب مع قيمتها وأهميتها (ب: 7 (1)

وتعد السياحة من الظواهر الاجتماعية التي نشأت منذ أن خلقت الأرض ومـا عليها حيث. وترتبط السياحة تقليديا بالتراث الحضاري للبشرية فعن طريق اكتشاف المناطق الأثرية

* عميد كلية تربية رياضية جامعة أسو ان ورئيس قسم الإدارة والترويح الرياضي. * * مدرس بقسم الإدارة والترويح الرياضي كلية التربية الرياضية جامعة أسوان. * * * * * * بقسم الإدارة و الثرويح الرياضي كلية التربية الرياضية جامعة أسوان. * * * * * باحثة دكتوراه بقسم الإدارة والتزويح الرياضي كلية التربية الرياضية جامعة أسوان 
ظهر ما يسمى بساحة الآثار، إلا أن التطور الهائل في مجال الاتصالات ووسائل المواصلات

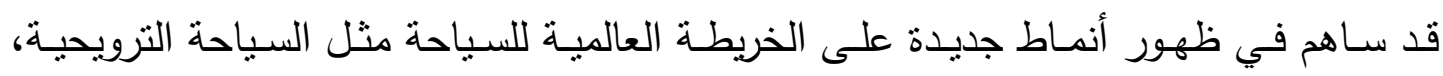

$$
\text { والعلاجية، والرياضية. (· ( : (1) }
$$

وتعد عمليـة وضـع الخطط والاستراتيجيات من العمليات الهامـة في شتى المجالات، وبخاصة السياحة حيث تعتبر من القطاعات الأهم والأكثر فاعلية، حيث تزايد الاهتمام بالسياحة كعلم وفن وممارسة وما لها من دور في الاقتصاد العالمي والقومي والمحلي. (r: سم) ومن هنـا فقطاع السياحة الترويحيـة وخاصـة الدوليـة منها يعتبر نشـاطا إنتاجيـا يقدم خدمات ومنتجات تساهم في زيادة الإنتاج ونمو الدخل القومي، كما يعمل من خلال مجموعة من المنشآت التي بدورها توظف عددا من الأبدي العاملة، التي تقدم خدماته للسائحين ويصدر

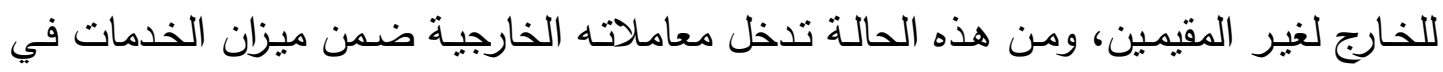

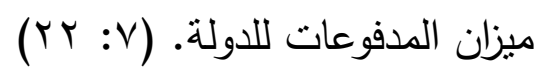

وتعتبر أسـوان زهرة الجنوب المصـري وإبداع مشتني عـالمي وبها العديد من المواقع السياحية، حيث تقع مدينة أسوان علي الضفة الثرقية للنيل علي مسافة 99 كمم جنوب القاهرة وهي حلقة اتصـال بين مصر والسودان وبذللك فهي البوابـة للقارة الأفريقيـة مما يجعلها مركزا تجاريا هاما. (· (1: · (1)

والسياحة في مصر دعامـة رئيسية من دعائم التتميـة الثـاملة فهي مصدر رئيسي

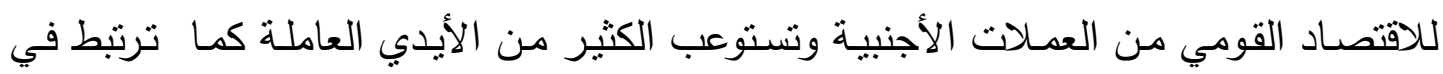
الوقت نفسـه بعدد كبير من الصناعات والخدمات المغذيـة والمكملـة مثنل النقل والمواصـلات والأغذية والمشروبات والإقامة والترفيه، مما جعلها صناعة المستقبل في مصر .

وتعد السياحة الترويحية من أهم أنشطة السياحة في مختلف دول العالم، ولم يعد يجذب السـائحين مجرد مشـاهدة الأحجار الأثرية القديمة ولكنهم يفضلون ممارسـة الأنشطة الترويحية 
المختلفة في أحضان الطبيعة، لذا لابد من الاهتمام بأنشطة السياحة الترويحية والتي تعمل على جذب السياحة لأسوان وتساهم في دفع عجلة التتمية الاقتصادية، حيث هناك اتجاه عالمي جديد

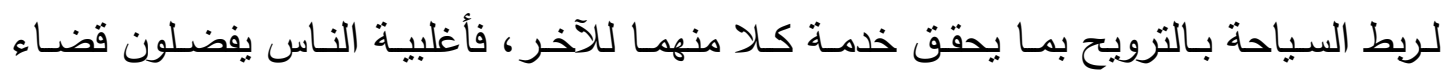
الأجازات ووقت الفراغ في ممارسة أوجه النشاط الترويح في الدول المتقدمة، لذا لابد وأن نهتم بمختلف الأنشطة الترويحيـة لتحقيق الجذب السياحي لمصر وإبراز الأمـاكن السياحة مدا قد يساعد في ذلك أن مصر تتمتع بجغرافيـة سياحية وظروف مناخيـة تجعلها صـالحة للسياحة الترويحية طوال العام.

وبناء على ما سبق فهناك العديد من المشكلات والعقبات التي تواجه السياحة الترويحية

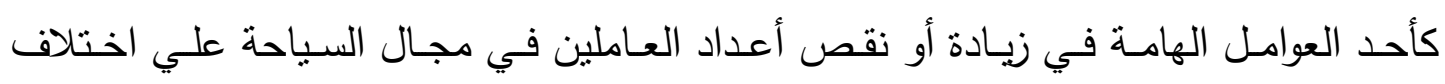

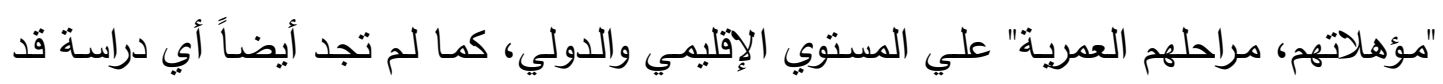

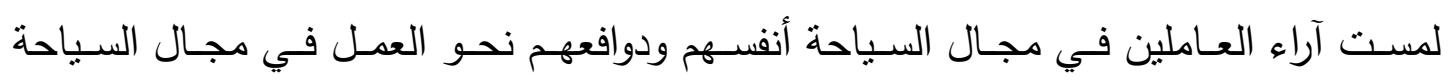
الترويحية بأسوان، وأن أغلب الدراسـات قد ركزت علي أراء أصحاب المشاريع السياحية وليس العاملين في مجال السياحة.

فمن خلال خبرة الباحثون وترددهم على الأماكن السياحية في أسوان لاحظوا نراجع في نسبة العاملين في مجال السياحة بأسوان وقد يرجع ذلك إلى مجموعة من العوامل من أبرزهيا انتشار بعض الأوبئة منل وباء كرونا، فضلا عن وجود قصور في بعض الجوانب الأخرى مثل بنل

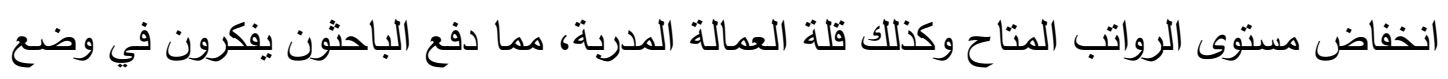
خطة مقترحة للعمل في مجال السياحة الترويحية في محافظة أسوان، وذلك للاستفادة من عملية الربط بين السياحة الترويحية ومتطلبات العاملين فيها، والمساهمة في إيجاد حلول جذرية لهم ورفع المستوى المعيشي والدخل القومي للدولة. 


\section{هدف البحث: - 2 - 20}

يهدف البحث إلى وضع خطة مقترحة للعمل في مجال السياحة الترويحية في محافظة

أسوان من خلال الإجابة على التساؤلات التالية:

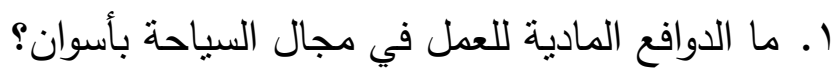

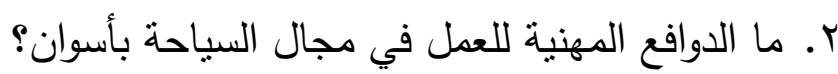

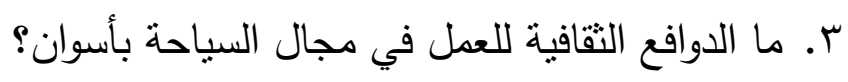

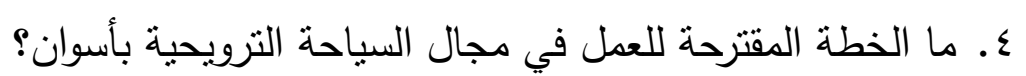

بعض المصطاح الواردة في البحث

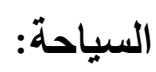

هي عملية الانتقال والإقامة التي يقوم بها الإنسان من موطن إقامته المعتاد إلي مكان

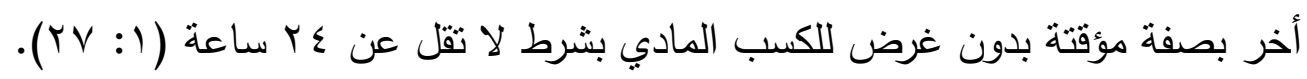

السياحة الترويحية:

هي من أقدم أنواع السياحة وتوفر للإنسان الراحة والانسجام بعيدا عن الروتين اليومي

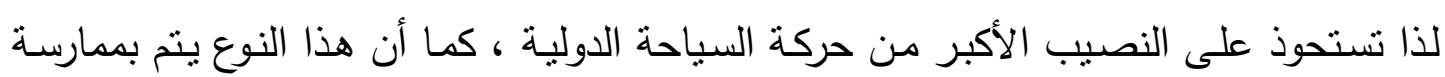

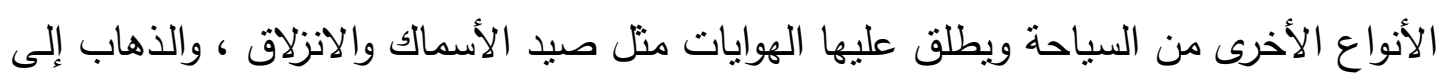

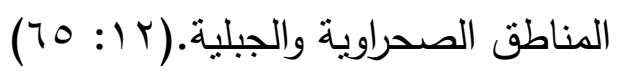

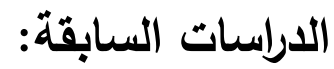

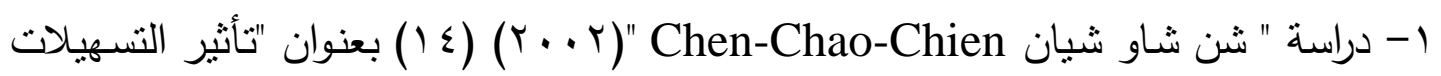

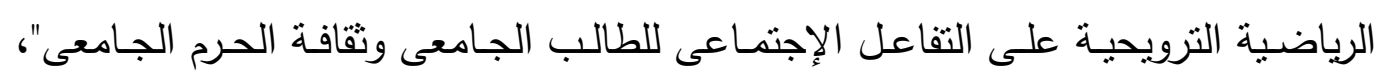
وتهدف الدراسة الي فحص العلاقة بين نوعية وإتاحة التسهيلات الترويحية الرياضية وأنماط الاطئي 
الأنشطة بالحرم الجامعى والتفاعل الاجتماعي للطالب من خلال تحليل اجتماعي لنقافات

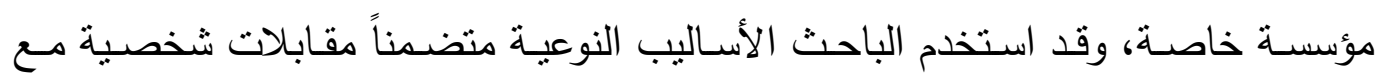
مديرين رياضيين ومديرى الأنشطة الطلابية وطلاب من جامعات مختلفة فى سان أنطونيو وتكساس، وكانت من أهم النتائج أن هناك علاقة دالة بين التسهيلات الترويحية والرياضية بالنسبة لاستخداماتها وهى: ثقافة الحرم الجامعي، التفاعل الإجتماعى، الأداء الأكاديمي، ونها،

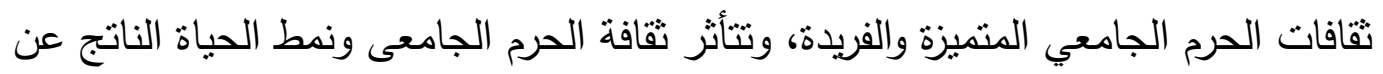

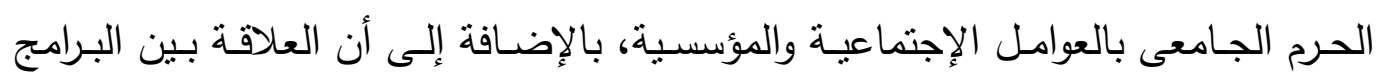
الرياضية الجماعية والتسهيلات الرياضية الترويحية عكسية.

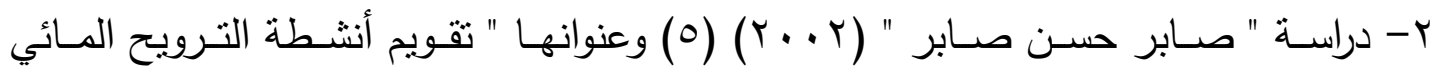
بالمشروعات السياحية في مصر " تهدف إلى تقويم أنشطة الترويح المـائي بالمشروعات

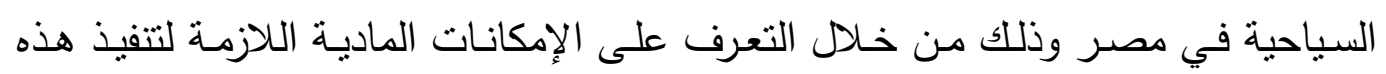
الأنشطة والقيادات البشرية المساعدة على ممارسة هذه الأنشطة وأنواعها وأسباب ممارستها

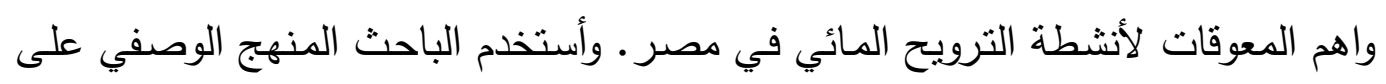

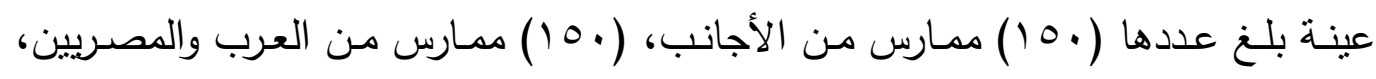
(V0) مـن القيـادات البشـرية تـم اختيـارهم بطريقـة عشـوائية. واسـتخدم الباحـث اسـتمارة

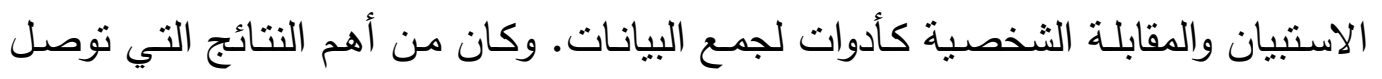
إليها الباحث: وجود قلة في الأنشطة الترويحية المائية داخل جمهورية مصر العربية، عدم

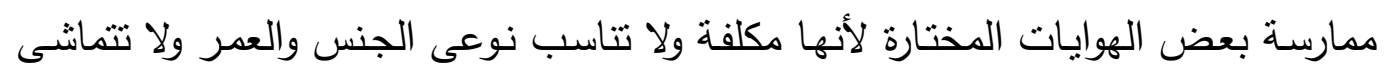

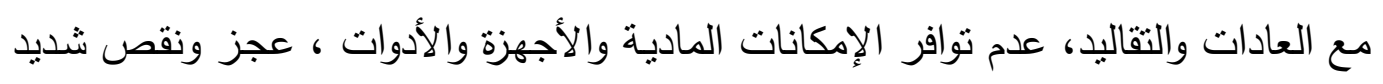

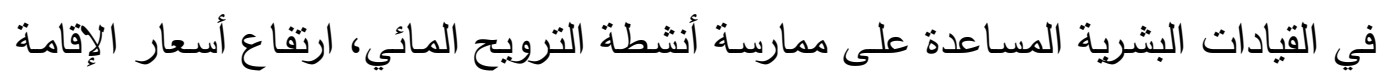
في المناطق السياحية.

ب- دراسـة "سيد عبد الحميد" (r . . r) (ع) وعنوانها "أسـاليب الجذب في بعض المؤسسـات الترويحيـة الاستتمارية " وتهدف إلى التعرف على أسـاليب الجذب في بعض المؤسسـات 


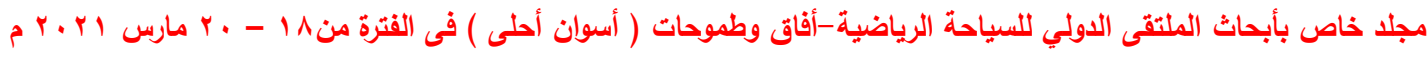

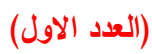

الترويحية الاستثمارية وذلك من خـلال التعرف على الخدمات والتشـهيلات المقدمة داخل المؤسسـات الترويحيـة الاسـتمارية والبـرامج المقدمـة والإمكانـات الماديـة والبشـرية ووسـائل الأعلام (المقروءة - المرئية - المسموعة) داخل هذه المؤسسات. واستخدم الباحث المنهج الوصفي "الدراسـات المسحية" على عينـة من المسئولين عن تتفيذ برامج الترويح بكل من الن

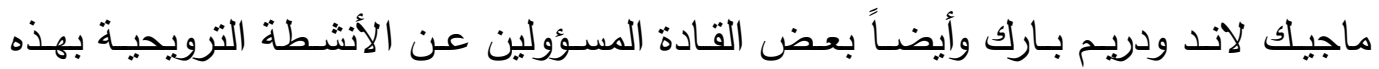

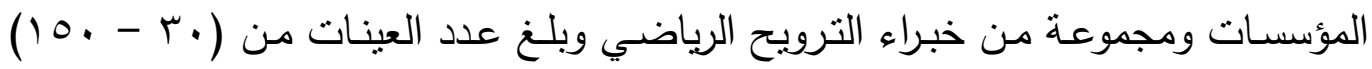
فرد. واستخدم الباحث استمارة الاستبيان والمقابلـة الثخصية والملاحظـة العلميـة كأدوات لجمع البيانات. وكان من أهم النتائج التي توصل إليها الباحث: توافر معظم أساليب الجذب لبانب

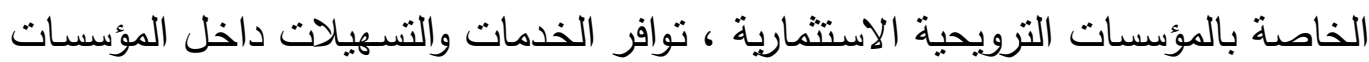
الترويحية الاستثمارية، توافر البرامج الترويحية المقدمة داخل هذه المؤسسات، وأيضـاً توافر العديد من والإمكانات المادية والبشرية بها وكذللك نوافر العديد من وسائل الأعلام (المقروءة - المسموعة - المرئية) بهذه المؤسسات.

ع - دراسـة "عبد الحميد محمد" (T . ץ) (T) وعنوانها "دراسـة مسحية للأنشطة الترويحية في القرى السياحية لمحافظة البحر الأحمر" تهدف إلى عمل مسح للأنشطة الترويحية بالقرى السياحية لمحافظة البحر الأحمر وذلك من خلال التعرف على الأنشطة الترويحية المتوفرة

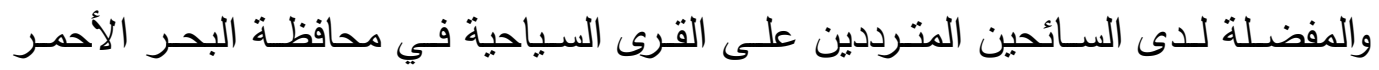

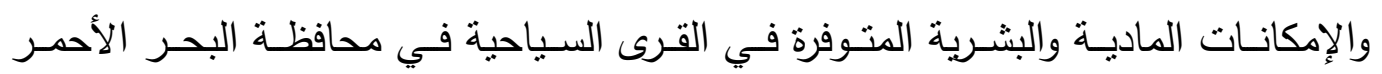
والمعوقات التي تواجه تتفيذ وممارسة هذه الأنشطة. واستخدم الباحث المنهج الوصفي على

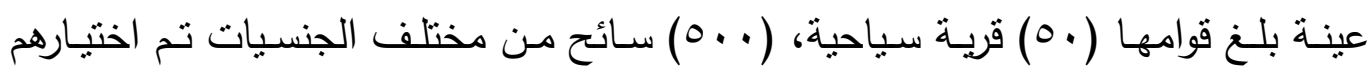

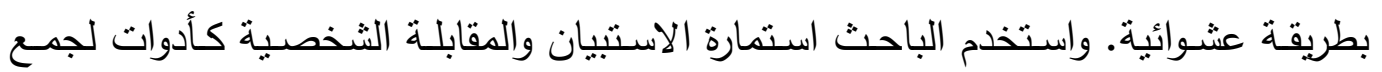
البيانات. وكان من اهم النتائج التي توصل إليها الباحث أن الأنشطة الترويحية الأكثر توفراً فـي محافظــة البحـر الأحمـر هـي (السـباحة - الغـوص - السـنوركلنج - الكـرة الطـائرة الثـاطئية) والأنشطة الترويحية الأكثر تفضيلاً لاى السائحين العرب هي (السباحة - كرة

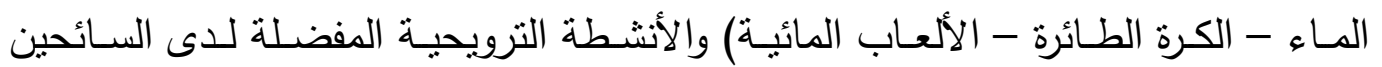


الأجانب هي (السباحة - الاستجمام على الثـاطئ - رحلات السفاري) والمكانات المادية الأكثر توفراً للأنشطة الترويحية هي ( حمام سباحة- شاطئ خاص بالقرية- مركز للغوص

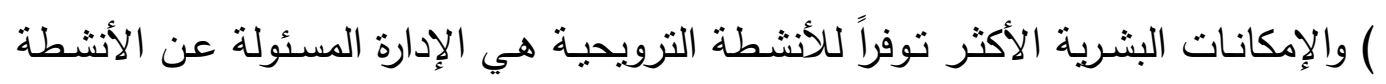

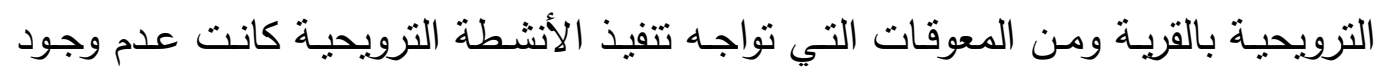
أخصائيين لتنفيذ أنواع معينة من النشاط وعدم وجود كوادر مؤهلة للعمل في مجال الأنشطة الترويحية بالقرى السياحية في محافظة البحر الأحمر .

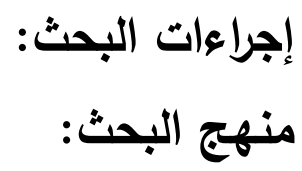

استخدم الباحثين المنهج الوصفى (أسلوب الدراسات المسحية) بخطواته وإجراءاته وذلك لمناسبته لتحقيق أهداف البحث.

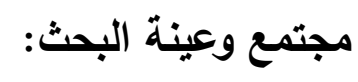

يتمثل مجتمع البحث فى العاملين في مجال السياحة بمحافظة أسوان والبالغ قوامهم

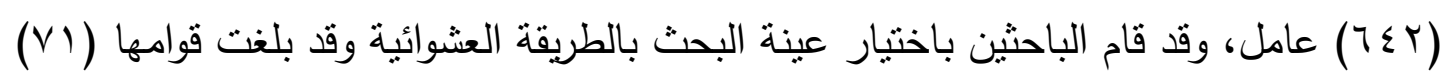
عامل. أدوات جمع البياتات:

\section{أولاً: تحليل الوثائق والسجلات:}

قام الباحثون بتحليل الوثائق والسجاتات الخاصة بوزارة السياحة والمنشآت السياحية وذلك للتعرف

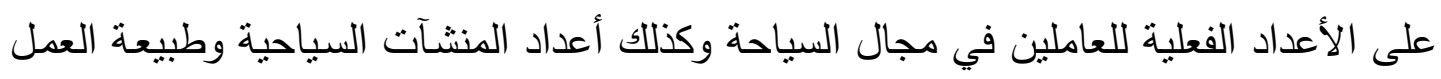
داخل تلك المنشآت في مجال السياحة الترويحية. ثانياً: المقابلة الشخصية: 
قام الباحثون بإجراء العديد من المقابلات الثخصية مـع عدد من المسئولين في وزارة السياحة من أجل التعرف علي طبيعة عمل في المنشآت السياحية في مجال السياحة الترويحية والتعرف علي أساليب وطرق ودوافع العمل في مجال السياحة. ثالثاً : استبيان دوافع العمل للعاملين في السياحة الترويحية بمحافظة أسوان: وهي استمارة من إعداد الباحثون واتبعوا في إعدادها الآتي: ا. تحديد هدف الاستبيان:

تم تحديد هدف الاستبيان وقد تمثل في التعرف على دوافع العمل في مجال السياحة الترويحية في محافظة أسوان . r. ت تحديد محاور الاستبيان:

من خلال إطلاع الباحثُن على الدراسـات السابقة، قام الباحثين بتحديد مجموعة من المحاور وقد تمثلت محاور الاستبيان الآتي:

$$
\text { دوافع مادية. }
$$

\section{r ـ ـ صياغة عبارات الاستبيان:}

قام الباحثثن بوضع مجموعة من العبارات لكل محور من محاور الاستبيان، وقد بلغ عدد العبارات (r ( ) عبارة، وقد قام الباحثين بعرض تلك العبارات على مجموعة من الخبراء في مجال الإدارة الرياضية والترويح قوامها (9) خبراء وذللك لإبداء الرأي في مدي مناسبة العبارات

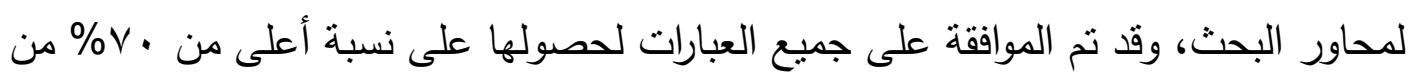
اتفاق الخبراء. 
ع ـ الصورة النهائية للاستبيان:

قام الباحثون بكتابة الاستبيان في صورته النهائية وذلك بترتيب العبارات تبعاً للمحاور المنتمية إليها بحيث تجمع العبارات الخاصة بكل محور من المحاور مع بعضها. ه. تصحيح الاستبيان: لتصحيح الاستبيان قام الباحثون بوضع ميزان تقديري ثثلاثي، وقد تم تصحيح العبارات كالتالي:

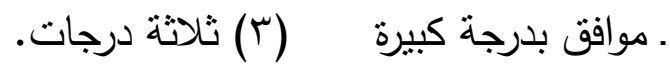
. موافق بدرجة متوسطة (Y) درجتان.

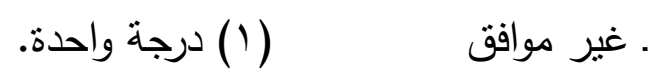

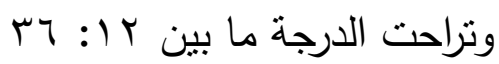
ד. المعاملات العلمية للاستبيان:

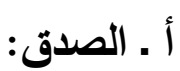

لحساب صدق الاستبيان استخدم الباحثون الطرق التالية: صدق المحتوى: (1) - (1)

قام الباحثون بعرض الاستبيان على مجموعة من الخبراء في مجال السياحة والترويح قوامها (9) خبراء وذلك لإبداء الرأي في ملاءمة الاستبيان فيما وضع من أجله، والجدول التالي (1) يوضح النسبة المئوية لآراء الخبراء على عبارات الاسنبيان. 


\section{جدول (1)}

النسبة المئوية لأراء الخبراء على عبارات استبيان دوافع العمل للعاملين

في مجال السياحة الترويحية بأسوان

\begin{tabular}{|c|c|c|c|c|c|c|}
\hline \multicolumn{6}{|c|}{ العبـــارات } & المحاور \\
\hline 0 & $\varepsilon$ & $r$ & r & 1 & رقم العبارة & \multirow{3}{*}{ الدوافع المادية } \\
\hline 9 & $\wedge$ & 9 & 9 & 9 & ت تكرارها & \\
\hline \multirow[t]{7}{*}{$\% 1 \ldots$} & $\% \wedge 9$ & $\% 1 \ldots$ & $\% 1 \ldots$ & $\% 1 \ldots$ & النسبة المئوية & \\
\hline & & $\wedge$ & v & 7 & رقم العبارة & \multirow{3}{*}{ لدوافع المهنية } \\
\hline & & $\wedge$ & 9 & 9 & تكرارها & \\
\hline & & $\% \wedge 9$ & $\% 1 \ldots$ & $\% 1 \ldots$ & النسبة المئوية & \\
\hline & ir & 11 & 1. & 9 & رقم العبارة & \multirow{3}{*}{ لدوافع الثقافية } \\
\hline & $\wedge$ & 9 & $\wedge$ & 9 & تكرارها & \\
\hline & $\% \wedge 9$ & $\% 1 \ldots$ & $\% \wedge q$ & $\% 1$. & النسبة المئوية & \\
\hline
\end{tabular}

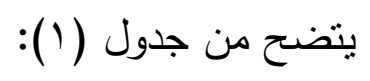

تراوحت النسبة المئوية لآراء الخبراء حول عبارات الاستبيان ما بين (9^\% : . . . ( \%)، وبذلك تم الموافقة علي جميع العبارات. (Y) (Y) صدق الاتساق الاخلي: لحساب صدق الاتساق الداخلي للاستبيان قام الباحثون بتطبيقه على عينة قوامها (ro) عامل من مجتمع البحث ومن غير العينة الأصلية للبحث، حيث تم حساب معاملات الارتباط بين درجة كل عبارة والدرجة الكلية للمحور الذى تتنمى إليه، كما تم حساب معاملات الارتباط بين درجة كل عبارة والدرجة الكلية للاستبيان ، كما تم حساب معاملات الارتباط بين درجة كل محور والدرجة الكلية للاستبيان، والجداول (Y)، (ب)، (ع) نوضح النتيجة. 


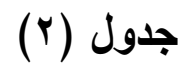

معامل الارتباط بين درجة كل عبارة والدرجة الكلية للمحور الأى تنتمى إليه

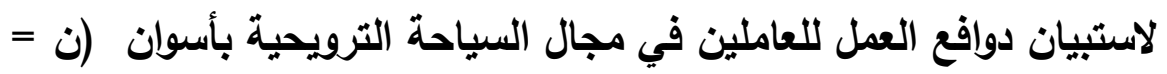

(ro

\begin{tabular}{|c|c|c|c|c|c|c|}
\hline \multicolumn{6}{|c|}{ العبــــارات } & المحاور \\
\hline 0 & $\varepsilon$ & r & r & 1 & رقم العبارة & \multirow{2}{*}{ لدوافع المادية } \\
\hline \multirow[t]{5}{*}{..$\wedge \wedge$} & r.Ar & 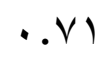 & .7 . &. .77 & معامل الارتباط & \\
\hline & & $\wedge$ & V & 7 & رقم العبارة & \multirow{2}{*}{ الدوافع المهنية } \\
\hline & &.$V 7$ & ת &..$\wedge V$ & معامل الارتباط & \\
\hline & ir & 11 & 1 . & 9 & رقم العبارة & \multirow{2}{*}{ الدوافع التقافية } \\
\hline &. .77 &.$V 7$ & $\because v \varepsilon$ & س & معامل الازتباط & \\
\hline
\end{tabular}

- تراوحت معاملات الارتباط بين درجة كل عبارة والدرجة الكلية للمحور المنتمية إلية ما

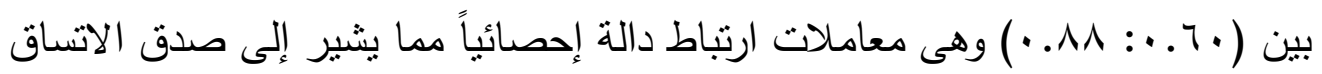

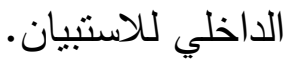




$$
\text { جدول ( ب (r) }
$$

معامل الارتباط بين درجة كل عبارة والارجة الكلية لاستبيان

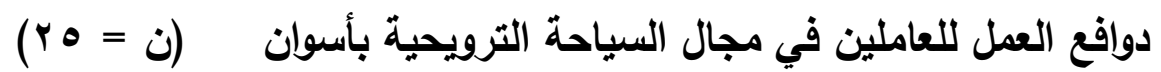

\begin{tabular}{|c|c|c|c|c|c|c|}
\hline \multicolumn{6}{|c|}{ العبــــارات } & المحاور \\
\hline 0 & $\varepsilon$ & r & r & 1 & رقم العبارة & \multirow{2}{*}{ الدوافع المادية } \\
\hline \multirow[t]{5}{*}{.71} & $\cdot v 1$ &.$V T$ &. .00 & .07 & معامل الارتباط & \\
\hline & & $\wedge$ & v & 7 & رقم العبارة & \multirow{2}{*}{ لدوافع المهنية } \\
\hline & & $.7 \varepsilon$ &..$\leqslant \varepsilon$ &. .09 & معامل الارتباط & \\
\hline & ir & 11 & 1. & 9 & رقم العبارة & \multirow{2}{*}{ الدوافع التقافية } \\
\hline &. .01 &. .77 & $.0 Y$ &. .79 & معامل الارتباط & \\
\hline
\end{tabular}

- تراوحت معاملات الارتباط بين درجة كل عبارة والدرجة الكلية للاستبيان ما بين (ع ــ ـ .

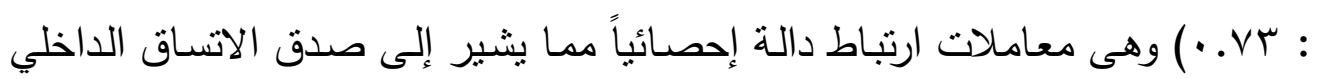

للاستبيان.

جدول (๕)

معامل الارتباط بين درجة كل محور وإلارجة الكلية لاستبيان دوافع العمل

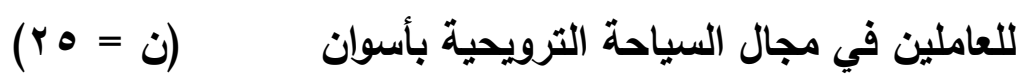

\begin{tabular}{|c|c|}
\hline معامل الارتباط & المحاور \\
\hline..$\wedge V$ & الدوافع المادية \\
\hline. $.7 V$ & الدوافع المهنية \\
\hline. .11 & الدوافع الثقافية \\
\hline
\end{tabular}




$$
\begin{aligned}
& \text { قيمة (ر) الجدولية عند مستوي دلالة ( ه .. ) = ד 9س. . }
\end{aligned}
$$

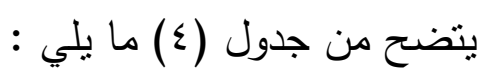

- تراوحت معـاملات الارتبـاط بين درجـة كل محسور والدرجـة الكليـة للاستبيان مـا بين

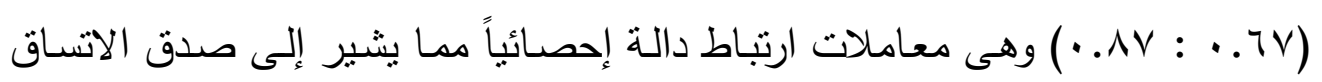

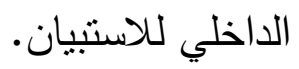

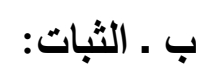

لحساب ثبات الاستبيان قام الباحثون باستخدام معامل ألفا لكرونباخ وذلك بتطبيقها على

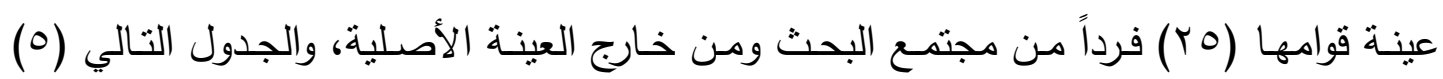
يوضح ذلك.

$$
\text { جدول (•) }
$$

\begin{tabular}{|c|c|}
\hline معامل الفا & المحاور \\
\hline.$\vee \vee \wedge$ & الدوافع المادية \\
\hline.$v_{0}$ & الدوافع المهنية \\
\hline.$V \varepsilon$ & الدوافع الثقافية \\
\hline.$\wedge \varepsilon$ & الدرجة الكلية \\
\hline
\end{tabular}

معاملات الثبات باستخدام معامل ألفا لكرونباخ لاستبيان دوافع العمل

$$
\text { للعاملين في مجال السياحة الترويحية بأسوان }
$$

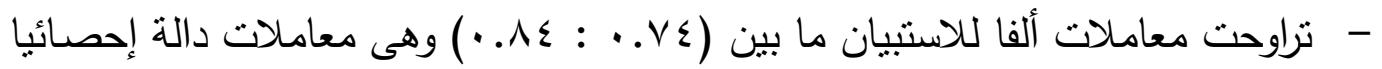
مما بشير إلى ثبات الاستبيان. 


\section{خطوات البحث:}

\section{أ- الاراسة الاستطلاعية:}

قام الباحثون بأجراء دراسة استطلاعية لأداة جمع البيانات حيث قام بتطبيقها على عينة

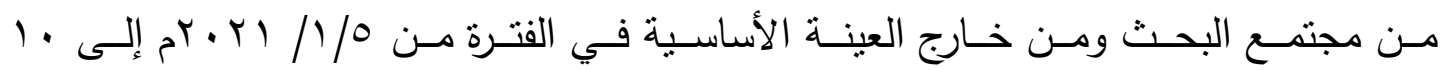

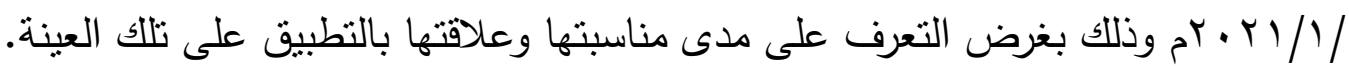

$$
\text { ب- تطبيق البحث: }
$$

بعد تحديد العينـة واختبـار أداة جمع البيانات والتأكد من صدقها وثباتها قام الباحثون

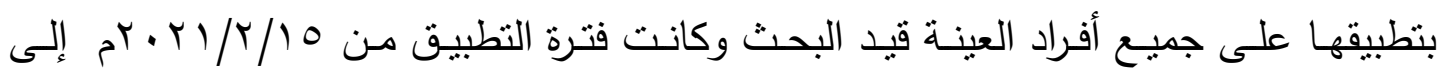

$$
\cdot r \cdot r) / Y / T_{0}
$$

ج- تصحيح استمارات الاستبيان: بعد الانتهاء من التطبيق قام الباحثون بتصحيح الاستمارات طبقاً للتعليمات الموجودة والموضحة سابقاً وبعد الانتهاء من عملية التصحيح قام الباحثون برصد الدرجات وذلك تمهيداً لمعالجتها إحصائياً.

\section{المعالجات الإحصائية: - الم:}

- معامل الازتباط.

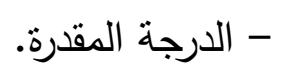

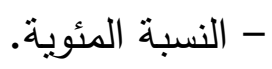

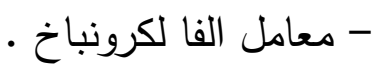

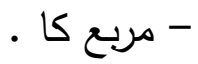

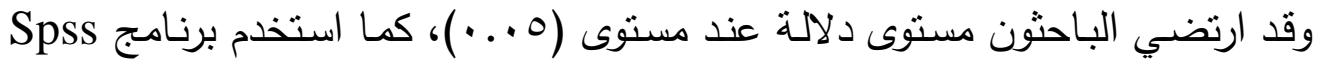

$$
\text { لحساب بعض المعاملات الإحصائية. }
$$
عرض النتائج ومناقشتها وتفسيرها: الإجابة علي التساؤل الأول الأي بنص علي: ما دوافع المادية للعمل فى مجال السياحة الترويحية للعاملين بأسوان؟ 
جدول (7)

الدرجة المقدرة والنسبة المئوية والترتيب ومريع كا لآراء العينة بالنسبة لعبارات

$$
\text { المحور الأول (الدوافع المادية) }
$$

\begin{tabular}{|c|c|c|c|c|c|c|c|}
\hline \multirow[b]{2}{*}{ قيمة كا' } & \multirow[b]{2}{*}{ النسئبــة } & \multirow[b]{2}{*}{ الدرجـــة } & \multicolumn{3}{|c|}{ الاستجابة } & \multirow[b]{2}{*}{ العبارات } & \multirow[b]{2}{*}{ r } \\
\hline & & & غوافق & موافـــق منتوسطة & كوافـــق & & \\
\hline 58.51 & 91.08 & 194 & & 19 & 52 & تتيح لي مرثب كبير & .1 \\
\hline 35.86 & 48.36 & 103 & 47 & 16 & 8 & 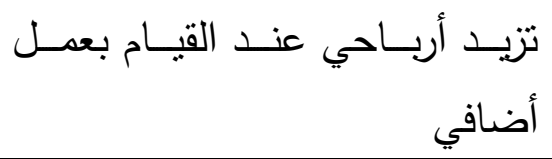 &.$r$ \\
\hline 45.66 & 70.89 & 151 & 6 & 50 & 15 & يفتح لي العمل في مجالات أخرى &.$r$ \\
\hline 94.85 & 95.77 & 204 & - & 9 & 62 & للخـــن علاقـات تـيح لـي السـفر &.$\varepsilon$ \\
\hline 21.66 & 58.69 & 125 & 40 & 8 & 23 & 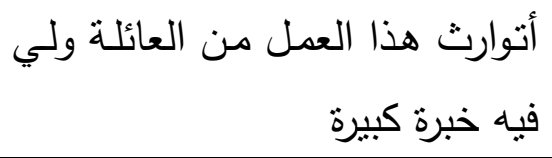 & .0 \\
\hline & 72.96 & 777 & & & & نة الكلية للمحور & 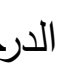 \\
\hline
\end{tabular}

$$
\text { يتضح من جدول (T): }
$$

- تراوحت النسبة المئوية لآراء عينة البحث في عبارات المحور الأول (الدوافع المادية) ما

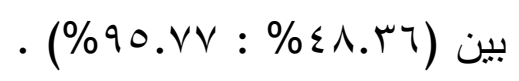

- توجد فروق دالة إحصائياً بين آراء عبنة البحث في عبارات (1، ع ) وفي اتجاه الموافقة

$$
\text { بدرجة كبيرة. }
$$

- توجد فروق دالة إحصائياً بين آراء عينة البحث في عبارة (r) وفي اتجاه الموافقة بدرجة متوسطة. 
- توجد فروق دالة إحصائياً بين آراء عينة البحث في عبارات (r، 0) وفي اتجاه عدم الموافقة.

الإجابة علي التساؤل الثاني الأي بنص علي: ما دوافع المهنية للعمل في مجال السياحة الترويحية للعاملين بأسوان؟ جدول (v)

الارجة المقدرة والنسبة المئوية وإلترتيب ومربع كا لآراء العينة بالنسبة لعبارات

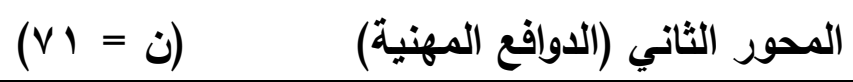

\begin{tabular}{|c|c|c|c|c|c|c|c|}
\hline \multirow[b]{2}{*}{ ق قيمة كا' } & \multirow[b]{2}{*}{ المسئوبـة النسة } & \multirow[b]{2}{*}{ الدرجــــة } & \multicolumn{3}{|c|}{ الاستجابة } & \multirow[b]{2}{*}{ العبارات } & \multirow[b]{2}{*}{ b } \\
\hline & & & غوافق & منوافق & كوافق & & \\
\hline 90.45 & 95.31 & 203 & - & 10 & 61 & أحب العمل في هذا المجال & .7 \\
\hline 35.52 & 83.57 & 178 & - & 35 & 36 & أجيد التعامل مع السائحين &.$v$ \\
\hline 66.37 & 92.02 & 196 & 1 & 15 & 55 & هذا العمل ممتع وغير روتيني &.$\wedge$ \\
\hline & 90.30 & 577 & \multicolumn{5}{|c|}{ الدرجة الكلية للمحور } \\
\hline
\end{tabular}

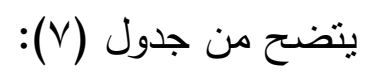

- تراوحت النسبة المئويـة لآراء عينة البحث في عبارات المحور الثاني (الدوافع المهنية)

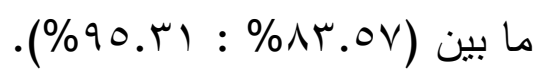

- توجد فروق دالة إحصائياً بين آراء عينة البحث في جميع العبارات وفي اتجاه الموافقة بدرجة كبيرة.

الإجابة علي التساؤل الثالث الذي بنص لئص علي:

ما دوافع الثقافية للعمل في مجال السياحة الترويحية للعاملين بأسوان؟ 


$$
\text { جدول (^) }
$$

الارجة المقدرة والنسبة المئوية وإلترتيب ومريع كا لآراء العينة بالنسبة لعبارات

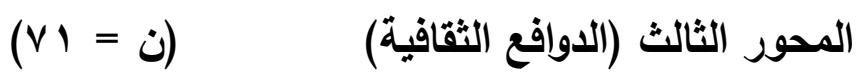

\begin{tabular}{|c|c|c|c|c|c|c|c|}
\hline \multirow[b]{2}{*}{ قيمة كا؟ } & \multirow[b]{2}{*}{ المئوية } & \multirow[b]{2}{*}{ 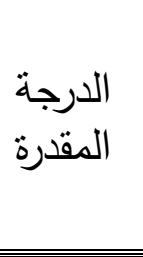 } & \multicolumn{3}{|c|}{ الاستجابة } & \multirow[b]{2}{*}{ 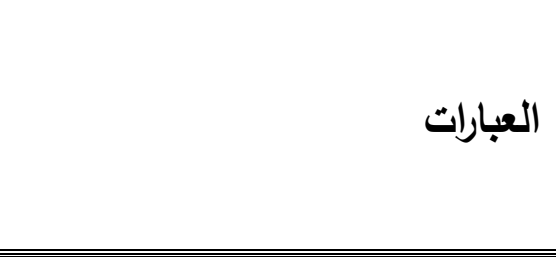 } & \multirow[b]{2}{*}{ s } \\
\hline & & & غوافق & منوسطة & كوافق كبيرة & & \\
\hline 48.70 & 87.79 & 187 & 6 & 14 & 51 & التعرف على ثقافات أخرى & .9 \\
\hline 82.17 & 94.37 & 201 & - & 12 & 59 & اكتساب بعض اللغات & .1 . \\
\hline 78.28 & 93.90 & 200 & - & 13 & 58 & اكتسب معلومات ومعارف جديدة & .11 \\
\hline 44.73 & 77.00 & 164 & 1 & 47 & 23 & بعض العرف العديـــ مـن عـادات وتقاليــ & .14 \\
\hline & 88.27 & 752 & لة للمحور & | & & & \\
\hline
\end{tabular}

$$
\text { يتضح من جدول (^): (1) }
$$

- تراوحت النسبة المئوية لآراء عينة البحث في عبارات المحور الثالث (الدوافع الثقافية)

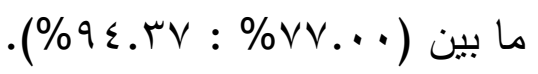

- توجد فروق دالة إحصائياً بين آراء عينة البحث في عبارات (9، • (، 1) (1) وفي اتجاه

$$
\text { الموافقة بدرجة كبيرة. }
$$

- توجد فروق دالة إحصـائياً بين آراء عينة البحث في عبارة (Y I) وفي اتجاه الموافقة

$$
\text { بدرجة متوسطة. }
$$


جدول (9)

الارجة المقدرة والنسبة المئوية والترتيب لدوافع العمل في مجال السياحة الترويحية (V) = للعاملين بأسوان

\begin{tabular}{|c|c|c|c|}
\hline الترتيب & النسبة المئوية & الدرجة المقدرة & المحور \\
\hline r & $\% 72.96$ & 777 & الدوافع المادية \\
\hline 1 & $\% 90.30$ & 577 & الدوافع المهنية \\
\hline r & $\% 88.27$ & 752 & الدوافع التقافية \\
\hline & 83.84 & 2106 & الدرجة الكلية \\
\hline
\end{tabular}

\section{يتضح من جدول (9) ما يلي:}

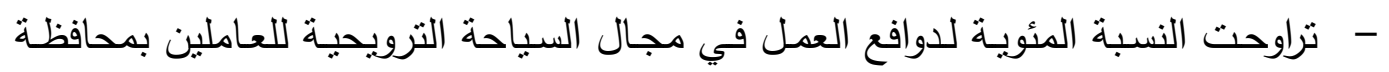

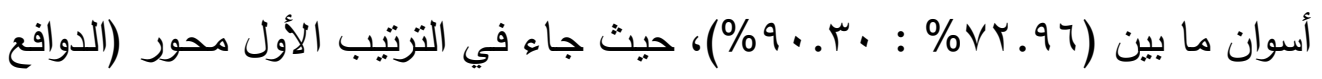

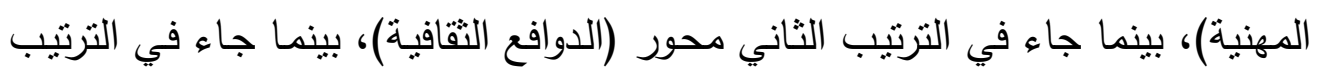
الثالث والأخير محور (الدوافع المادية).

ويرجع الباحثون نتائج جدول رقم(T) إلى أن العمل في مجال السياحة يتيح للعاملين بها

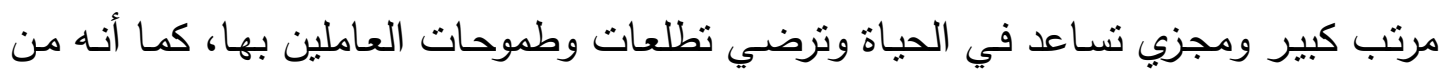

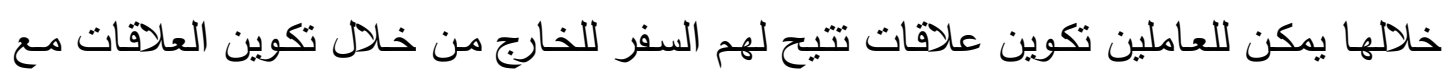

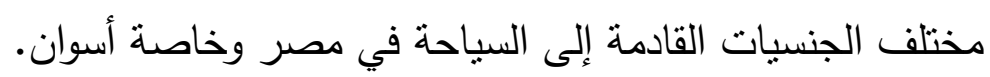

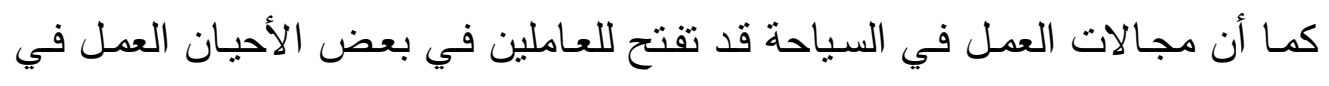

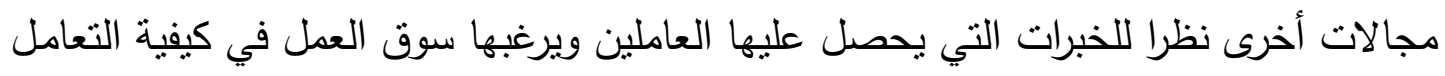
مع السائحين والجهات المختلفة وخاصة الأجنبية. 
وبالرغم من ذلك فإن العمل في مجال السباحة لا يزيد من أرباح العاملين عند القيام بعمل أضافي نظرا لأنه بشغل معظم الوقت لارتباطه بفريق السائحين المكلف بمرافقتهم خلال

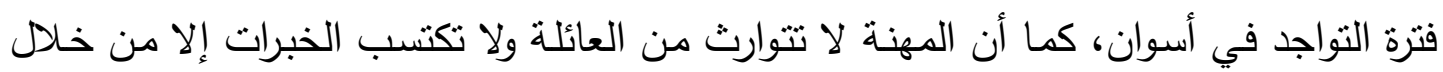
العمل المباشر فيها.

كما يعزو الباحثون نتائج جدول V) إلى أن هناك العديد من الدوافع المهنية التي تدفع

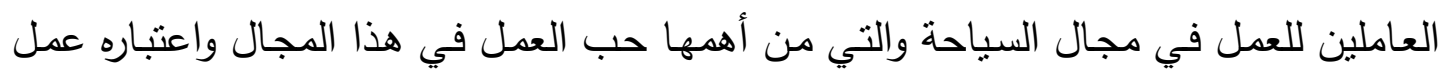
متع ولا يوجد به الثق الروتيني وكذلك إجادة التعامل مع السائحين مما يسهم في زيادة دافعية كية العاملين نحو الإقبال علي العمل في مجال السياحة.

ويرجـع البـاحثون نتائج جدول رقم (^) إلى أن من أهم الدوافع التقافيـة التي تتيحها طبيعة العمل في مجال السياحة بالنسبة للعاملين من خلال التعرف علي ثقافات أخرى مختلفة

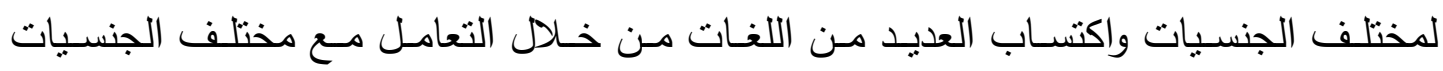
واكتساب العديد من المعلومات والمعارف الجديدة، كما أنها تتيح بشكل متوسط التعرف علي

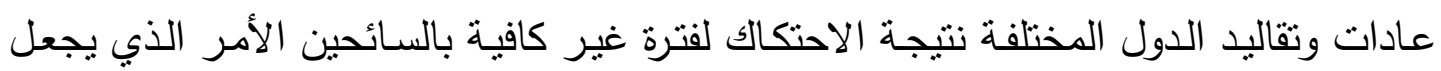
فرصة الاختلاط الكامل بالثقافات محدودة نظرا لمحدودية الوقت.

وهذا مـا أنشارت إليه دراسـة "هاله الصبى" ( ( . . r) (1 (1) حيث كان من أهم النتائج

إمكانات السياحة الرياضية تعتبر من أهم أساسيات نجاح وترويج السياحة الرياضية في مصر -

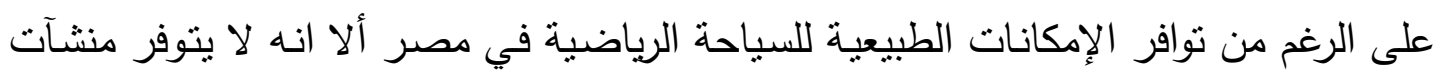
وكوادر قادرة على استغلال هذه الإمكانات لزيادة الدخل القومي وترويج هذا النمط السياحي. هناك قصور في أداء التسويق والأعلام لدورهم في نجاح السياحة الرياضية المصرية.

ويرجع الباحثون نتائج جدول رقم (9) إلى أن دوافع العاملين المرتبطة بالمهنة من أهم

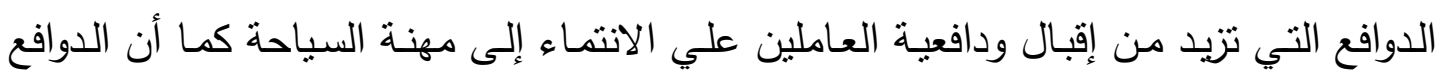
الأخرى تشكل قدراً كبيراً في دافعية العاملين نحو المهنة والمتمثلة في الدوافع الثقافية التي تتمي لتي 
لدي الفرد الثقافات المختلفة وتزيد من معلوماته ومهاراته وكذللك الدوافع المادية التي تكون الدخل الاقتصادي للفرد وتزبد من موارده المادية.

\section{الإجابة علي التساؤل الرابع الأي بنص علي:}

ما الخطة المقترحة للعمل فى مجال السياحة الترويحية للعاملين بأسوان؟

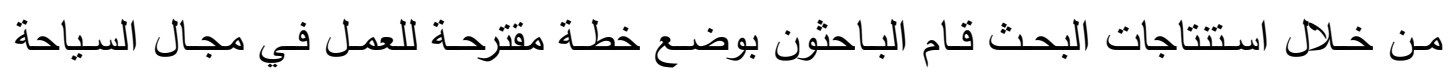
الترويحية بمحافظة أسوان وكما هو موضح في جدول رقم ( • (1)

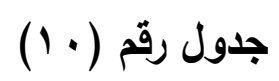

الخطة المقترحة للعمل في مجال السياحة الترويحية في محافظة أسوان

\begin{tabular}{|c|c|c|}
\hline الملاحظات & المحتوى & المحاور \\
\hline & 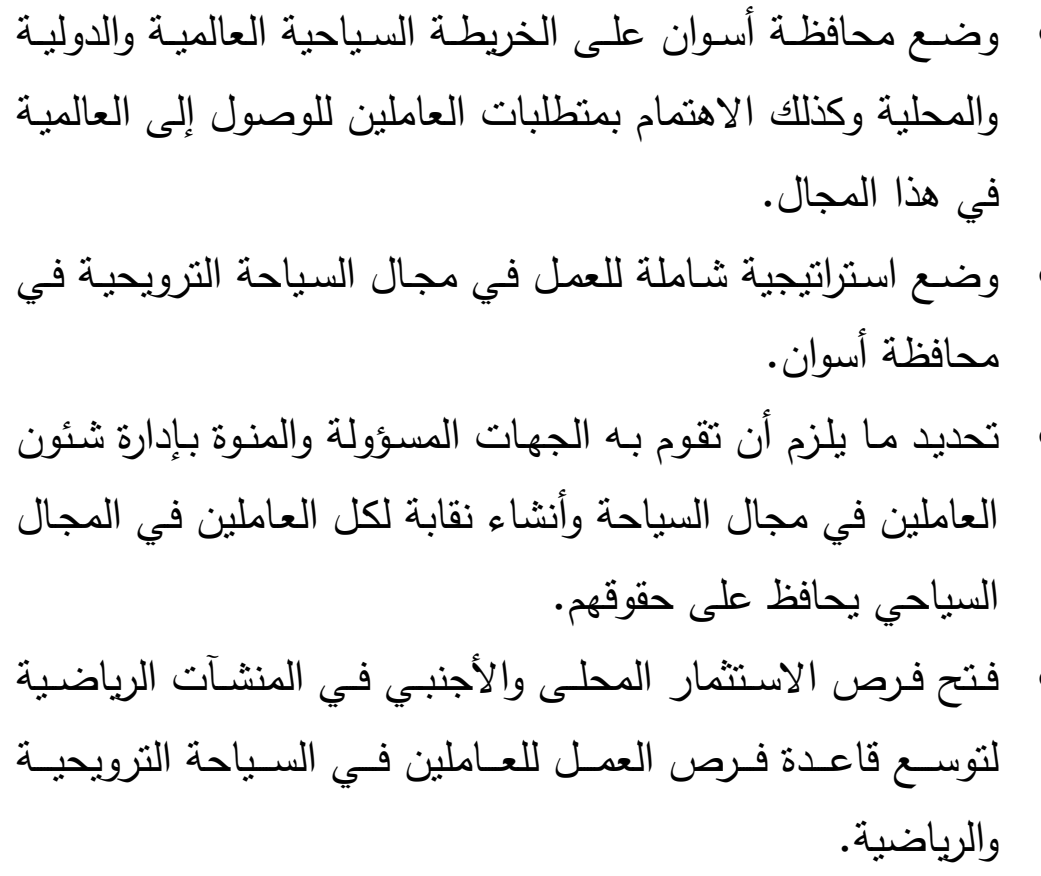 & أهداف الخطة \\
\hline & 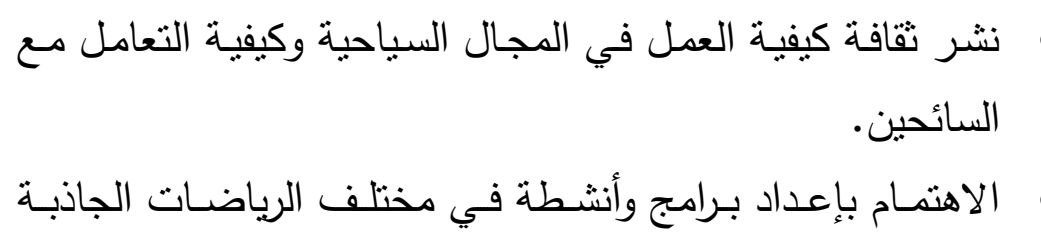 & للخطة السياسـة العامـة \\
\hline
\end{tabular}




\begin{tabular}{|c|c|}
\hline 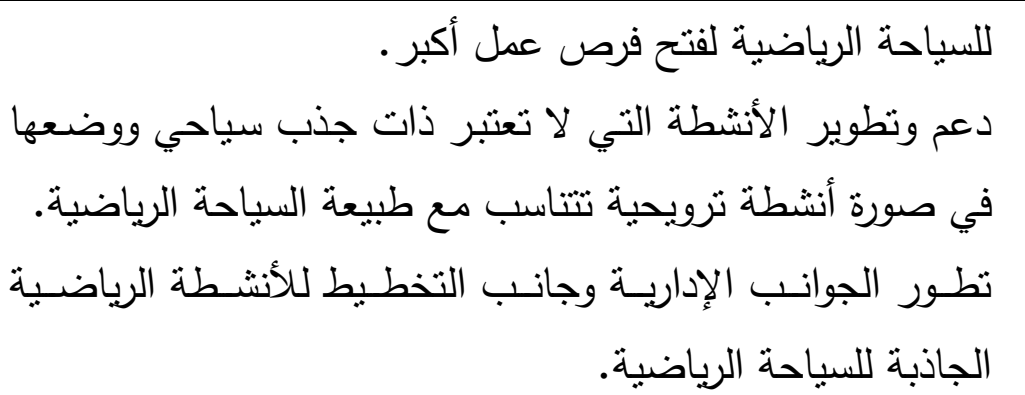 & \\
\hline موادر بنية تحتية (منشآت) & مقومات الخطة \\
\hline 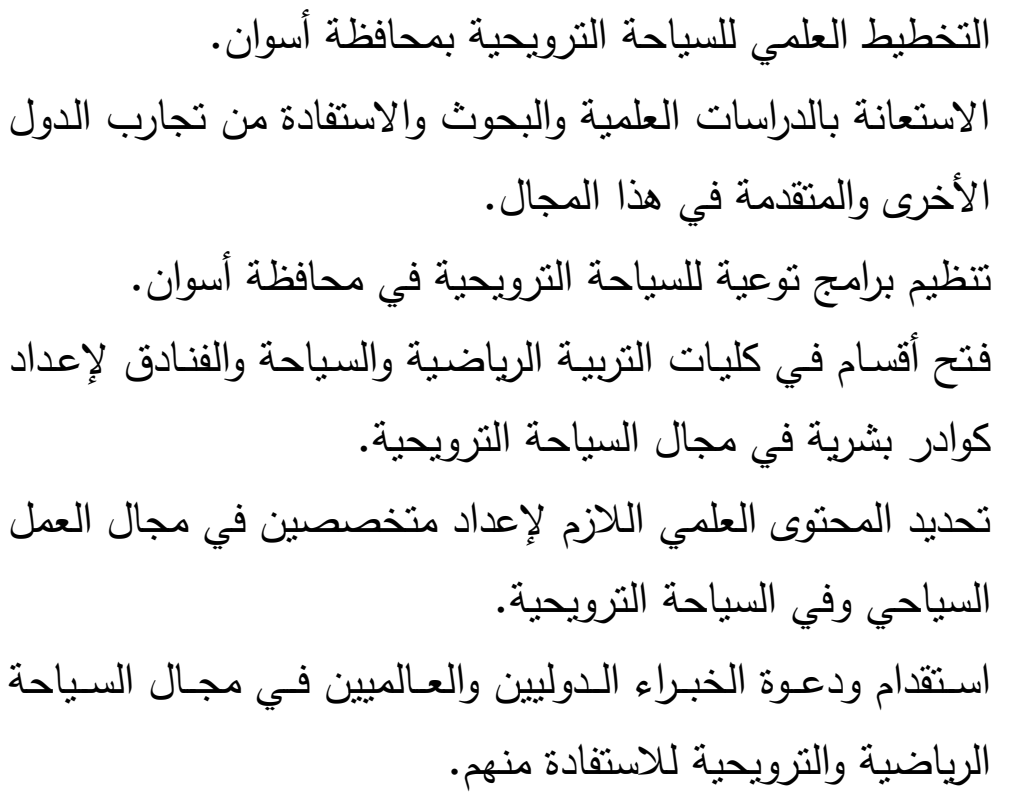 & إجراءات الخطة \\
\hline
\end{tabular}




\begin{tabular}{|c|c|}
\hline 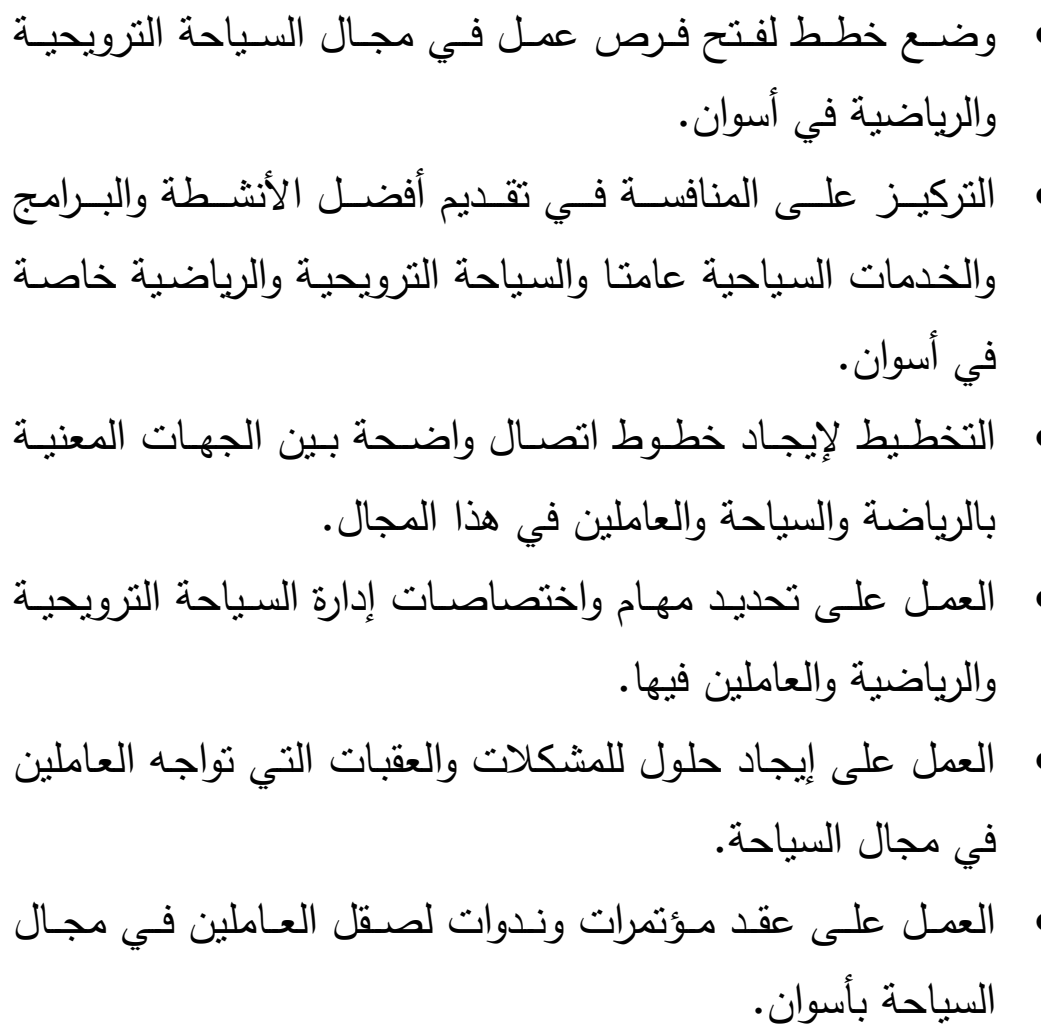 & \\
\hline 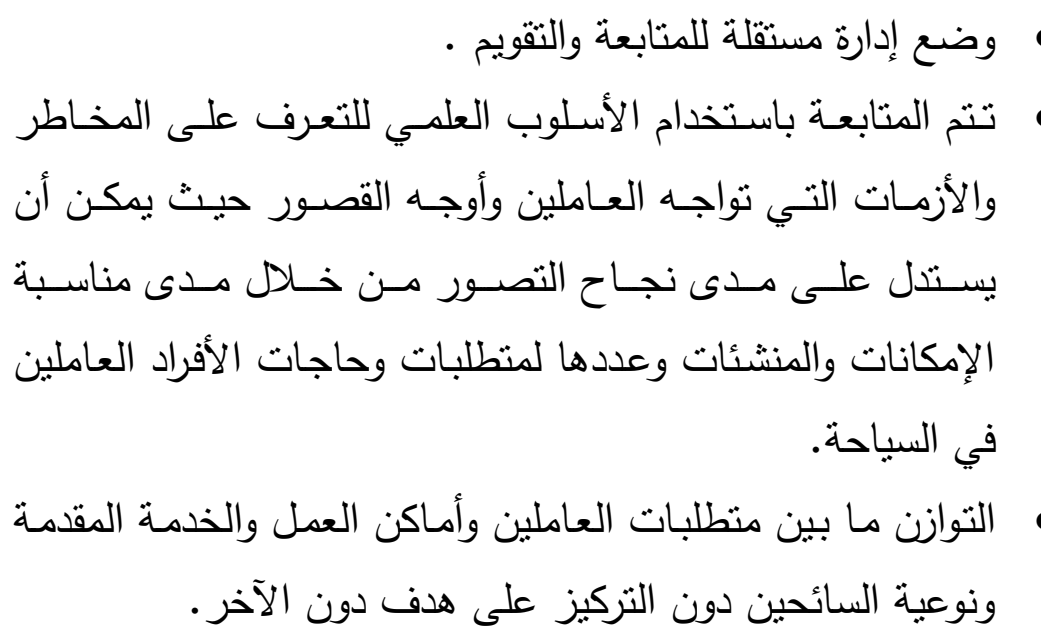 & والتقويم \\
\hline
\end{tabular}


ا . وجود العديد من دوافع العمل المادية التي تدفع العاملين في مجال السياحة بمحافظة

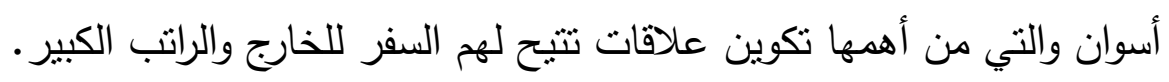

r. وجود العديد من دوافع العمل المهنية التي تدفع العاملين في مجال السياحة بمحافظة

أسوان والتي من أهمها حب العمل في هذا المجال وأن العمل ممتع وغير روتيني.

r. وجود العديد من دوافع العمل الثقافية التي تدفع العاملين في مجال السياحة بمحافظة

أسوان والتي من أهمها اكتساب بعض اللغات والمعلومات والمعارف الجديدة.

ع. أكثر دوافع العمل التي تدفع العاملين للعمل في مجال السياحة بمحافظة أسوان هي ولي ولهي

الدوافع المهنية تليها الدوافع الثقافية تليها الدوافع المادية.

التوصيات:

\section{في ضوء نتائج البحث يوصي الباحثين بما يلي:}

ا. العمل على تطبيق الخطة المقترحة في الدراسة من خلال وزارتي الرياضة والسياحة. r. العمل على استغلال المقومات الطبيعية والجغرافية في مجال السياحة الترويحية وفتح فرص عمل للشباب.

r. الاهتمام باستضافة البطولات والأحداث الرياضية مما يزيد من فرص العمل وزيادة دخل الأفراد كذلك زيادة الدخل القومي للاولة .

ع. ضرورة وضع استراتيجية شاملة للسياحة الترويحية والرياضية من قبل وزارتي الرياضـة والسياحة ومراعاة الفئة العاملة في هذا المجال. ه. تشجيع الاستثار من خلال فتح فرص الاستثمار وكذلك فرص عمل ودعم المستشرين للارتقاء بالسياحة الرياضية والترويحية. 


\section{المراجع}

\section{أولاً : المراجع العربية:}

ا ـ إبراهيم عبد المقصود: السياحة والرياضة، سلسلة دار الفكر العربي، القاهرة، 999 (م.

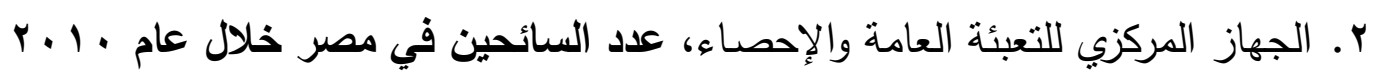

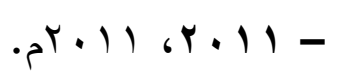

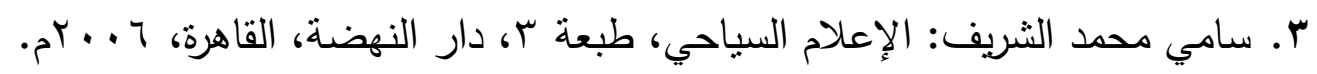
ع. سيد عبد الحميد: أساليب الجذب في بعض المؤسسات الترويحية الاستثمارية ، رسالة

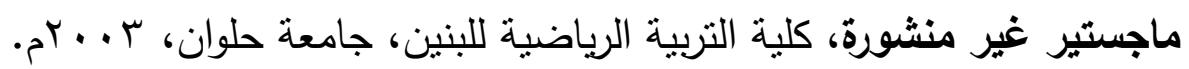
ه. صابر حسن: تقويم أنشطة الترويح بالمشروعات السياحية في مصر ، رسالة ماجستير

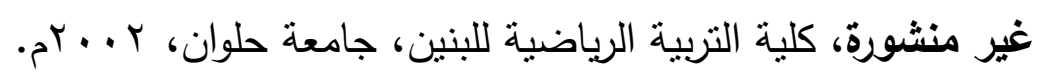

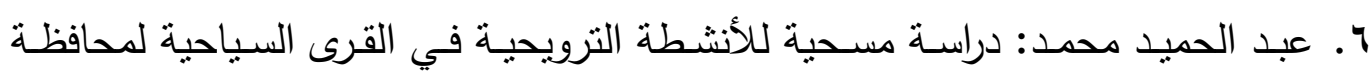

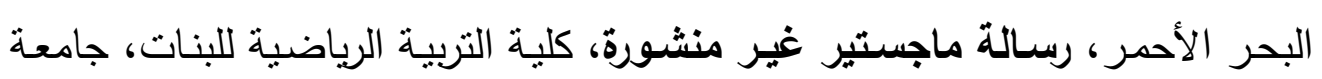

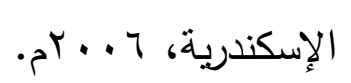

V. محمــ البنـا: اقتصــاديات السـياحة والقتــادق، طـا، مكتبـة الزهـراء الثـرق، القـاهرة،

$$
\cdot r+r
$$

^. محمـود طلبـة: سـيكولوجية التـرويح وأوقــات الفــراغ، طب، مكتبـة الفـلاح، القـاهرة،

$$
\text { . } 9
$$

9. محمود طلبة: مدخل إلى الترويح وأوقات الفراغ، طץ، دار المعرفة، المنيا، r ا ـ rم. • 1 . محمود محمد خلف: جغرافية مصر السياحية، دار أنون للنشر، الأقصر، V V. . Yم.

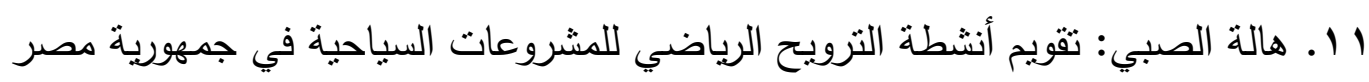

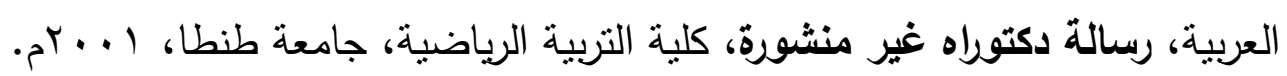
r ا. هدى لطيف: السياحة النظريـة والتطبيق، الثـركة العربية للنشر والتوزيـع، القاهرة، . ) $99 \varepsilon$ 


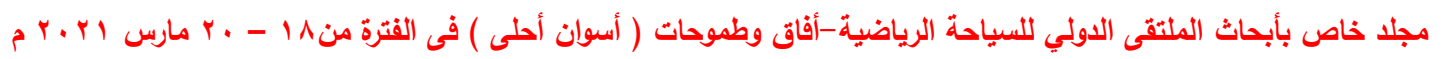
(العدد الاول)

rا ا ـ يسري إبراهيم دعبس: السياحة المصرية بين المقومات والتحديات، رؤية انتربولوجيا

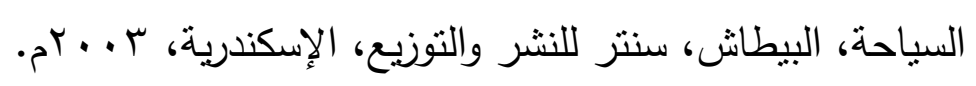

ثانياً: المراجع الأجنبية:

14. Chen Chao Chien, the impact of recreation sports facilities on un iversity student's social interaction and campus culture, phd, university of the lncarnate word, Carleton William, 2002. 


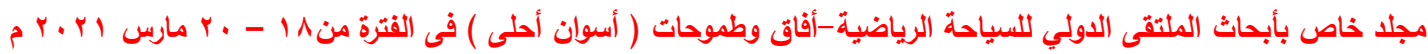

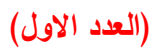

\title{
A proposed plan to work in the field of recreational tourism in Aswan Governorate
}

\author{
* Prof. Dr. Adel Abdel Moneim Makki \\ ** Dr. Walid Rizk Amin \\ *** Dr. / Mohamed Hamed Fathy \\ **** Researcher / Iman Ahmed Abdel Shafi
}

\section{Introduction and research problem:}

Tourism in general and recreational tourism in particular has become one of the most important service industries in all developed and developing countries alike, as a result of the advantages that are achieved from this activity, whether from an economic or social point of view ... etc., and Egypt is considered one of the countries that rely heavily on Tourism Industry We find that Egypt ranked 75th out of 139 countries in terms of the global tourism and travel competitiveness scale for 2011 (World Economic Forum) in a way that is not commensurate with the importance and position of this country. In line with the difficult conditions that Egypt is going through at the present time, the Egyptian tourism sector has become in dire need to search for several means through which it can improve the mental image of Egypt as a tourist destination and work to attract many markets to Egypt in a manner commensurate with its value and importance $(2: 16)$

Tourism is one of the social phenomena that have arisen since the earth and what is on it was created. Tourism is traditionally linked to the civilizational heritage of mankind. Through the discovery of archaeological areas, the so-called archeology square appeared, but the tremendous development in the field of communications and means of transportation has contributed to the emergence of new patterns on the 


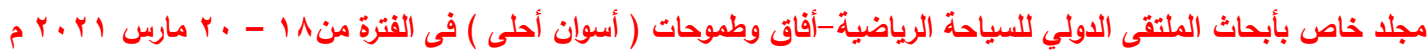

global map for tourism such as recreational, medical and sports tourism. (10:11)

The process of developing plans and strategies is one of the important processes in various fields, especially tourism, as it is considered one of the most important and most effective sectors, as there has been an increase in interest in tourism as science, art and practice and its role in the global, national and local economy. (3: 3)

Hence, the recreational tourism sector, especially the international one, is considered a productive activity that provides services and products that contribute to the increase in production and the growth of national income, its foreign transactions within the balance of services in the balance of payments of the state. $(7: 22)$

Aswan is the flower of the Egyptian south and the creativity of a global winter resort and has many tourist sites, as the city of Aswan is located on the eastern bank of the Nile at a distance of $899 \mathrm{~km}$ south of Cairo, and it is a link between Egypt and Sudan, and thus it is the gateway to the African continent, making it an important commercial center. (10:10)

Tourism in Egypt is a major pillar of comprehensive development, as it is a major source of foreign currency for the national economy and absorbs a lot of manpower, and is associated with a large number of nutritious and complementary industries and services such as transportation, transportation, food and beverages, accommodation and entertainment, which made it the future industry in Egypt.

Recreational tourism is one of the most important tourism activities in various countries of the world, and it no longer attracts tourists just to see ancient archaeological stones, but they prefer to practice various recreational activities in the embrace of nature, so it is necessary to pay attention to recreational tourism activities that work to 


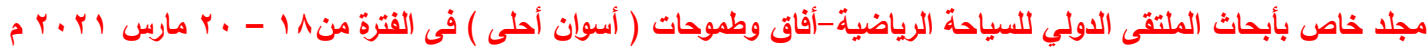
(العدد الاول)

attract tourism to Aswan and contribute to advancing economic development. Where there is a new global trend to link tourism with recreation in a way that achieves the service of each of them to the other, the majority of people prefer to spend vacations and free time in practicing aspects of recreational activity in developed countries, so we must pay attention to various recreational activities to achieve tourist attractions to Egypt and highlight tourism places, which may help in This is because Egypt has a tourist geography and climatic conditions that make it suitable for recreational tourism throughout the year.

Based on the foregoing, there are many problems and obstacles facing recreational tourism as one of the important factors in the increase or decrease in the number of workers in the tourism field, regardless of their "qualifications, age stages" at the regional and international level, and also did not find any study that touched the opinions of workers in the field Tourism themselves and their motives towards working in the field of recreational tourism in Aswan, and that most studies focused on the opinions of the owners of tourism projects and not workers in the field of tourism.

Through the experience of researchers and their hesitation to tourist places in Aswan, they noticed a decline in the percentage of workers in the tourism field in Aswan, and this may be due to a set of factors, the most prominent of which are political events and the consequent instability of the security situation, as well as the spread of some epidemics such as the Corona epidemic, as well as the presence of deficiencies in Some other aspects, such as the low level of available salaries as well as the lack of trained workers, which prompted researchers to think of developing a proposed plan to work in the field of recreational tourism in the Aswan Governorate, in order to benefit from the process of linking recreational tourism with the requirements of its 


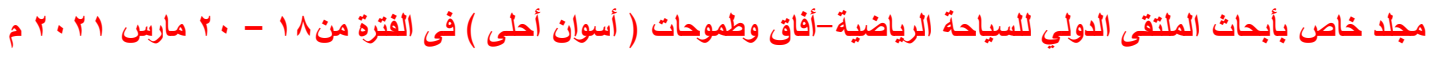
(العدد الاول) (مان)

workers, and to contribute to finding radical solutions for them and raising the level The subsistence and national income of the state.

\section{Conclusions:}

1. The existence of many material work motives that motivate workers in the tourism field in Aswan Governorate, the most important of which is the formation of relationships that allow them to travel abroad and earn a large salary.

2. There are many professional work motives that motivate workers in the tourism field in Aswan Governorate, the most important of which is the love of working in this field and that work is fun and not routine.

3. The existence of many cultural work motives that drive workers in the field of tourism in Aswan Governorate, the most important of which is the acquisition of some new languages, information and knowledge.

4. The most work motives that drive workers to work in the tourism field in Aswan Governorate are professional motives, followed by cultural motives, followed by material motives. 


\section{Recommendations:}

In light of the research results, researchers recommend the following:

1. Work to implement the plan proposed in the study through the Ministries of Sports and Tourism.

2. Working on exploiting the natural and geographical factors in the field of recreational tourism and opening job opportunities for young people.

3. Interest in hosting tournaments and sporting events, which increases job opportunities and increases the income of individuals as well as increases the national income of the state.

4. The necessity of developing a comprehensive strategy for recreational and sports tourism by the ministries of sports and tourism, taking into account the working group in this field.

5. Encouraging investment by opening investment opportunities as well as job opportunities and supporting investors to promote sports and recreational tourism. 